\title{
Identifying Factors of Sustainable Tourism in West Sumatera: A Qualitative Analysis
}

\author{
Emrizal $^{1}$, Primadona ${ }^{2}$ \\ \{emrizal@yahoo.com ${ }^{1}$,pdmamarafif@gmail.com²\} \\ 1,2 Politeknik Negeri Padang, Kampus Limau Manis, Padang, Sumatera Barat
}

\begin{abstract}
This study aims to determine the potential of West Sumatra as one of the world's tourism destinations in the development of sustainable tourism. West Sumatra is the only region in Indonesia that won the Best Platinum Province Award for Investment and Platinum Province Potential in the category of Tourism in Indonesia Attractiveness Award 2018. Sustainable tourism is to take full account of current and future economic, social and environmental impacts, addressing the needs of visitors, tourism industry, environment and host community. This research was conducted quantitative and qualitatively by survey method by collecting data using indept-interview, observation, FGD and questionnaire involving six locations in West Sumatra which had very interesting tourist attractions. Inequality that occurs in this study is the achievement of sustainable tourism goals by optimizing service to the needs of tourists but by paying attention to the norms and cultural values of the Minang people who hold a strong religious principle called adat bersandi sarak and sarak basandi Kitabullah. This study very interesting because the development of the tourism industry in West Sumatra must be adapted to the culture of the Minang ethnic community, halal tourism which is one of the advantages of West Sumatra has made this area the Best Halal Tourism Destinations and No. 1 in the world today. The principle of the Minang ethnic community, one of which is by developing halal tourism, makes West Sumatra able to provide tourist specifications at the international level by becoming the main destination for Muslim tourists. The limitation of this research is that it has not been able to thoroughly explore the main factors in the development of sustainable tourism in West Sumatra with a focus on the local cultural order.
\end{abstract}

Keyword: sustainable tourism, destinations, halal tourism, culture, norms, values

\section{Introduction}

At present, Tourism has been recognized internationally as a sector of economic drive with raw materials that are never used up. The WTO (World Tourism Organization) estimates that the number of international tourists (inbound tourism) in the world will reach around 1,046 billion people in 2010 [1] and 1,602 billion people in 2020. Of these, 231 million people are in the East Asia region and 438 million people are in the Pacific. These tourists will be able to create world income of USD 2 trillion in 2020. The ten most popular tourist destination countries are France, the United States, China, Spain, Italy, England, Turkey, Germany, Indonesia and Mexico. The number of tourists coming in the ten largest countries is motivated by many factors. The two main factors influencing were the number of popular tourist objects and the large number of MICE (Meetings, Incentives, Conferences, Exhibitions) activities held.

The number of foreign tourists visiting Indonesia has relatively increased. The number of tourists to Indonesia in 2013 was 8 million people. The lowest number of foreign tourists (tourists) to Indonesia or low season occurs at the beginning of each year. While the number of foreign tourists to Indonesia experienced a peak or peak season in the middle and end of the 
year. West Sumatra as one of the tourist destinations in Indonesia which is located on the west coast of the island of Sumatra, has considerable potential, especially in the field of tourism and marine. Its very strategic position as the center of government, trade and regional transportation in West Sumatra is more value than other regions.

The diversity of tourism products is the basic capital of government policy on the determination of tourism and culture as one of the leading sectors in accelerating the economy in West Sumatra. According to the results of preliminary interviews and observations made by the author there are several issues in the development of tourism in West Sumatra, including: (1) the problem of reforming integrated tourism destinations that have not been able to be carried out thoroughly, (2) Preservation of Culture, by mobilizing Minang cultural arts studios, Nagari children's games, and carrying out events based on Minang arts that are capable of supporting tourism have not been carried out in an organized and continuous manner, (3) Increasing partnerships and collaboration with various related parties (Ministries / Provinces / Districts / Cities) both inside and outside the country , traditional institutions, tourism organizations, art organizations, educational institutions, tourism creative industries, tourism-conscious groups, print and electronic media, tourism investors and the public in order to accelerate the increase in income and tourism development have not been able to be implemented because if the party goes alone.

Tourism and the creative economy make a significant contribution to the Indonesian economy. The impact of tourism on National GDP in 2008 was Rp 153.25 trillion (3.09\%) and continued to increase in 2010 amounting to 261.1 trillion (4.1\%) of National GDP. GDP creation in the tourism sector occurs through the expenditure of foreign tourists, the government tourism budget, the expenditure of foreign tourists and tourism business investments which include: tourist attraction business, tourism area business, tourism transportation services, travel services, food and beverage services, accommodation provision, organizing entertainment and recreation activities, organizing meetings, incentive trips, conferences and exhibitions, tourism information services and others (Renstra Kemenparekraf, 2012-2016: XXVII).

West Sumatra is one of the national and international tourist destinations, this is supported by maritime tourism which is very extraordinary and also a highly developed cultural tourism. In addition tourism development that refers to the West Sumatra 2015-2020 RPJM (Long Term Development Plan) places tourism as one of the regional visions to make West Sumatra a leading sustainable tourism destination in the world. West Sumatra is one of the tourist destinations both domestically and internationally. In addition to the natural beauty that is very mesmerizing the condition of the West Sumatra region which has a complex culture and customs especially influenced by the culture of the Minang people who are very strong with religion, making the tourism sector is one that must be taken into account in regional development and development. The contribution of the tourism sector in the economy of West Sumatra in 2014 was Rp.17,302 billion, an increase in 2015 to Rp.43,912 billion this value reached more than $34.53 \%$ of the total West Sumatra GRDP itself (BPS, 2015).

During this time cultural tourism or marine tourism in West Sumatra has also been very well known such as Bukittinggi, Mentawai, Angso Duo Island, Cingkuak Island, Mandeh tours and many other areas that have extraordinary views for natural and marine tourism that are worth visiting . The excitement of tourism in West Sumatra was also marked by the success of winning the world halal competition award in the 2016 World Halal Tourism Awards, on December 7, 2016, making all elements more focused on promoting tourist destinations in West Sumatra to the world. The number of foreign tourist visits to West Sumatra in November 2015 
rose by 21.61 percent with a total of 4,811 visitors. In September 2015 tourist arrivals reached 3,956, November rose to 4,8116 people arriving through Minangkabau Intersection Airport and Teluk Bayur Port and this was able to contribute 0.62 percent of total travelers visiting Indonesia as many as 777,480 people (BPS, 2016).

This makes it important to explore the potential for sustainable tourism development in West Sumatra that takes into account the characteristics of culture and customs and the values of the Minang ethnic community. This paper consists of four parts, the first part reveals the gap that occurs in sustainable tourism, the second part will describe important indicators in sustainable tourism, the third part will reveal the potential of sustainable tourism in West Sumatra and the fourth part will find obstacles and weaknesses weaknesses in the development of sustainable tourism that will be able to become the main target. The limitation of this study is that it has not been able to see overall the main factors in the development of tourism which are linked to the characteristics of the people in West Sumatra.

This research is increasingly interesting because West Sumatra is one of the areas prone to earthquake and tsunami and has been hit by a number of earthquakes several times in 2004, 2009 and 2012. Seeing the condition of this area, it is increasingly interesting to know the potential of West Sumatra in developing sustainable tourism.

\section{Literatur Review}

This subsection contains operational definitions of a number of key themes and related writings from the literature available in this proposal and relevant previous studies / studies that have been carried out by other researchers as well as the results of proposers' research in relevant fields with the proposals discussed in an integrated manner.

\section{Sustainable Tourism}

This section will discuss the definition of sustainable tourism to be able to explain or be able to get relevant information on the topics discussed. Operational definitions in sustainable tourism are needed to explore more deeply about sustainable tourism. Research and views on sustainable tourism have been discussed previously, as [2] defines sustainable tourism as tourism that respects both locals and travelers, elevates cultural heritage, and observes values and the environment. The discussion of sustainable tourism also observes environmental sustainability and also takes into account the life of the local community which is where tourists travel to get pleasure.

Whereas according to the World Tourism Organization [3] sustainable tourism is tourism that takes full account of current and future economic, social and environmental impacts, addressing the needs of visitors, industry, the environment and the host community. This definition shows that tourism should be sustainable and must consider many factors that affect tourism, such as the economy, society, environment, the needs of visitors, the host community and the tourism industry as a whole [4]. Another view [5] states that sustainable tourism can only be achieved if behavior such as the government as a regulator, stakeholders, and tourists in terms of being ecological, economical and ethically responsible and therefore, sustainable tourism must be seen as a destination for the tourism industry that can occur if managed properly Sustainable tourism also seeks deeper involvement from the local population, which provides opportunities for local people and earn a living (UNWTO Annual Report) in 2013. This is certainly not an easy task, but to enable certain sustainability principles to be achieved must be followed by environmental, economic and socio-cultural aspects of tourism development and 
together must have the right balance to ensure long-term sustainability of tourism [3]. Providing tourism destinations as a tool to be able to carry out sustainable tourism also needs to be carried out as a supporting factor (Barros, 2011).

\section{Parameters of Sustainable Tourism}

Socially, tourism is beneficial because it has the potential or impact on employment, redistribution of income and alleviation of poverty; contributing to the awakening of the environment, providing insights into native craft festivals and traditions, and also providing improvements to physical and social infrastructure, theoretically also improving overall health and social and economic well-being (SGUN, 1999). Also, the principles of sustainability refer to the environmental, economic and socio-cultural aspects of tourism development, and an appropriate balance must be established between these three dimensions to ensure long-term sustainability [3]. Thus, sustainable tourism must support all aspects that exist and have an economic, social and environmental impact.

All elements of understanding of sustainable tourism above will be used as a measurement parameter to measure sustainable tourism in West Sumatra, including regarding service quality, quality of travel, food and beverage conditions, impact on society, tourism support efforts, regional physical conditions and the ability to preserve tourist attractions. All of these parameters refer to some of the notions that have been stated above. In this research sustainable tourism contains several aspects, including:

a. Referring to the understanding of sustainable tourism by some experts, the use of environmental resources is a key element in the development of tourism, continues to maintain the ecological process because this is very important and helps to preserve natural heritage and biodiversity.

b. Maintaining and respecting the socio-cultural authenticity of the tourism area or the host, preserving the cultural heritage that has been built and also paying attention to the order of their lives and traditional values contained, and contributing to intercultural understanding and tolerance.

c. Must be sure and certain that there is a decent long-term economic operation, provide socio-economic benefits for all stakeholders who have been involved in a fair distribution, including paying attention to stable employment opportunities and seeing income opportunities and trying to provide social services for the people who are masters home, and generally contribute to poverty alleviation.

Some of the above will be a parameter in producing sustainable tourism that is happening now in West Sumatra.

\section{Marketing of Sustainable Tourism}

According to [6] despite the fact that marketing is often regarded as an enemy of sustainability, destination authorities and other tourism actors must realize that strategic marketing should be used to achieve tourism destination policies. He further explained that if this was done, the right target market would be identified and this would bring the maximization of economic benefits at the local level without jeopardizing local resources. In addition, he stated that appropriate communication strategies must support the government for tourism destinations that are able to communicate their message and promote environmentally friendly practices locally. All of these explanations show a clear concern about sustainable tourism 
marketing [7]. According to [8] provides a very clear explanation of sustainable tourism marketing by showing that there are three main factors to support sustainable tourism.

The first factor is people's understanding that tourism is a phenomenon of sustainable living practices. The second he points out is the connection of stakeholders to the tourism system and the latter is achieving sustainable marketing goals through profit and non-profit institutions. In simple words, as mentioned in the previous section on the definition of sustainable tourism, this is about a continuous process or a living system in which all tourism stakeholders must be aware of their responsibilities in working towards sustainable tourism.

\section{Impact of Tourism}

Tourism development is widely considered to be able to improve the local economy [9]. Most studies encourage the development and promotion of tourism, which is believed to bring various benefits especially for local development [10]. A study on Jeju Island, Korea [9], shows that tourism development has a positive impact on the economy, which includes increasing investment, development and infrastructure, increasing employment opportunities, contributing to regional income, namely increasing local taxes. According to [10] and [5] revealed that all factors will have an impact on tourism such as beach sports, community motivation in providing tourism needs and all that has an impact on regional income, thus the need for tourism development is carried out.

\section{Methodology}

\section{Research Design}

This research was conducted using questionnaires, interviews and observations as well as Focus Group Discussions (FGD) to produce supporting factors for sustainable tourism in West Sumatra. Respondents will be divided into 2 categories: foreign tourists and domestic tourists. The number of respondents was 300 tourists who visited the research location. Each location is targeted at 50 respondents to be able to accommodate the views of tourists regarding tourism in West Sumatra.Travelers will be asked questions about sustainable tourism, including:

a. Accommodation facilities

b. Standard hotel

c. Food and drink quality

d. Transportation system

e. Travel comfort when choosing transportation

f. Service quality

g. Tourists get information about culture, social, norms, economic conditions of the population

h. businesses are favorites with a willingness to preserve traditional cultural heritage and values

i. Consumption of local goods to support local families

j. Avoid littering

k. Take service from responsible business environments

1. Local people are aware of the protection of tourist and environmental destinations

$\mathrm{m}$. Local people are involved in tourism activities

n. Tourists are aware of nature, culture, heritage and sites

o. Service providers are sensitive to environmental pollution and natural degradation 
p. Friendly local people

q. Tourists tend to take responsibility for their actions

r. A view that is not harmful to nature

s. Regional characteristics were studied

t. Understanding the culture of the local community by looking at tourism products

\section{Research sites}

This research was conducted in 6 regions in West Sumatra which are regencies and cities consisting of Tanah Datar, Pesisir Selatan, Padang, Sawahlunto, Pariaman and Bukittimggi cities. Each loasi will produce 50 questionnaires given to tourists.

\section{Data analysis}

This research is carried out in a qualitative analysis by describing the results of the study in accordance with the parameters that have been determined.The data that has been collected from wisatwan will be grouped based on variables that have been detailed in the form of questions so that they are able to see which variables are currently the main factors as supporting and which variables currently inhibit the development of sustainable pariwiata in West Sumatra. This is seen from the answers of respondents based on the liqueur scale so that they can see the level of tourism readiness at the research location.

\section{Finding and Discussion}

\section{Characteristics of Respondents}

The results of the study revealed the characteristics of respondents based on gender, age, education, occupation and purpose of travel.

Table 1. Gender of the respondents

\begin{tabular}{lcc}
\hline \multicolumn{2}{c}{ Gender } \\
\hline Gender & Number of respondent & Persentase(\%) \\
\hline Male & 99 & 33 \\
\hline Female & 201 & 67 \\
\hline
\end{tabular}

In general, tourists visiting the study location were women with a percentage of 67 while men were 33 percent.

Teble 2. Age of the respondent

\begin{tabular}{ccc}
\hline \multicolumn{2}{c}{ Age } \\
\hline Age & Number of respondent & Persentase(\%) \\
\hline $15-25$ & 28 & 9.3 \\
\hline $26-35$ & 89 & 29.7 \\
\hline $36-45$ & 36 & 12 \\
\hline
\end{tabular}




\begin{tabular}{lcc}
\hline $46-55$ & 70 & 23.3 \\
\hline $56-65$ & 49 & 16.4 \\
\hline $65+$ & 28 & 9.3 \\
\hline
\end{tabular}

In general, tourists who visit have ages 26 - 35 and then aged 46 - 55 with percentages of 29.7 and 23.3.

Table 3. Occupation The Respondents

\begin{tabular}{lcc}
\hline \multicolumn{1}{c}{ Categories } & Occupation & \\
\hline Student & Number & of Respondent \\
\hline Housewife & 25 & Persentase \\
\hline Company Employee & 49 & 8.3 \\
\hline Govt. Employee & 71 & 16.3 \\
\hline Private Business & 78 & 23.6 \\
\hline Other & 52 & 26 \\
\hline
\end{tabular}

Based on the results of surveys conducted in general, tourists who visit have diverse jobs but the dominant ones are housewives and civil servants with the largest percentage of 23.6 and 26 percent.

Table 4. Purpose Travel

\begin{tabular}{lccc}
\hline & & Purpose of Travel & \\
\hline \multicolumn{1}{c}{ Purpose } & & Number of respondent & Persentase \\
\hline Pleasure & 197 & 65.7 & \\
\hline Family & 79 & 26.3 \\
\hline Business & 16 & 5.3 \\
\hline Other & 8 & 2.6 \\
\hline
\end{tabular}

For the purpose of tourism, 65.7 percent is for pleasure or travel and 26.3 percent for family while for business purposes only 5.3 percent.

\section{Findings and Discussion}

West Sumatra is the majority of the Minang ethnic community and has been embracing the culture of wandering and generally plunging into the field of entrepreneurship while in regard to tourism only a few years ago, in fact to develop tourism has a great opportunity. The vision and mission of the government for tourism also only emerged a few years ago.Based on the parameters that have been determined in measuring the factors of sustainable tourism in 
West Sumatra in this study has outlined the parameters that have been determined. To find out the accommodation facilities that are available in several research locations the results are not yet able to say overall good. Accommodation facilities referred to in this study are everything that is needed by someone when traveling. According to the results of the study, of all respondents who were asked for their views, there were still many needs that were not available. More than 60 percent of respondents answered that they were not satisfied with the existing accommodation facilities.

This can be seen from the needs of tourists starting from those entering West Sumatra. Even not a few of the travel agencies have not been able to provide suitable servants. The results of interviews with industry or entrepreneurial actors stated that there was a limited capacity of each facility provider for tourists, both from the capabilities of existing human resources and physical facilities, for example in the Bukittinggi area where it was very difficult to provide accommodation facilities due to limited parking space that made all travel tourists are very disturbed. There are also areas such as the City of Batusangkar, 4-star international accommodation, there is only one hotel while the other is only a 3 -star hotel with very minimal facilities. Though this area is one of the national and even foreign tourist destinations. If we look at the readiness of the local community in each location, it is very far from good service and for accommodation facilities is very lacking. This is caused by several factors, namely the public is not ready to face tourism or tourism, the people of West Sumatra are not smiling people in serving tourists, this is influenced by the culture of the people who have not been able to adapt to the needs of tourists. In addition to the factors of the Minang ethnic community who live wandering as entrepreneurs, not so many are interested in tourism even though the potential is very large.

The results for hotel standards according to the results of interviews and questionnaires with respondents contained 54 percent answered in accordance with the wishes of tourists while the rest said it was not in accordance with the wishes of tourists. This is due to several factors, the quality of the hotel has not been able to international standards, as in terms of providing tourist needs at the hotel. Hotel owners still see local needs and are still supported by the values and culture that have been attached to the life of the Minang ethnic community. So that it has not been able to compete internationally. Besides that, the hotels are very limited in number and this makes it difficult for tourists to get lodging. For example, tourists who come to the Batusangkar area are more likely to stay in Bukittinggi because the hotel in Batusangkar is only 2 pieces. As a result, there is a lot of time spent on the trip so that tourists do not achieve this desire and this also applies to other areas. Whereas in the blood there are so many interesting tourist attractions to visit.

For food and beverage quality parameters have a pretty good satisfaction value that is 83 percent of tourists are satisfied with the quality of food and drinks they met during the tour. While the rest of tourists feel dissatisfied and there is no view or choice. For food and drinks in West Sumatra, it is very well known not only in West Sumatra but has been known to almost all of Indonesia and even to neighboring countries such as Malaysia with the name Padang cuisine. The food with the name Padang cuisine has been very liked by most Indonesians so that the Padang cuisine brand is very well known all this time. Tourists who travel in West Sumatra find it very easy to find good quality food and beverages and this also makes tourists feel satisfied with the quality of the food. Foods that are famous in Indonesia such as rendang taste in West Sumatra, where rendang is the most delicious meal in the CNN version of 2017. Padang 
satay and other complementary foods are also in great demand all this time and this is also a major consideration for tourists in giving answer.

The transportation system provided by both industries such as the travel bureau is considered still unsatisfactory. Standards that are perceived as normal and not yet good or provide good service. As many as 43 percent of tourists who feel satisfied the rest argue that they are not satisfied and even around 3 percent have no choice because there is no comparison for them to judge. This was answered by local tourists in their own area so it was difficult for them to give an answer because so far no one had traveled out of the area. In the view of wisatwan, the quality of transportation is still below perfection and even in terms of quality of transportation itself, it is still not able to provide according to the wishes of consumers. In general, tourists outside the region have not felt satisfaction for this transportation system. Likewise, the comfort of the trip during the tour was assessed by the respondents as not so good. Convenience in this trip is also considered to include accompanying guides and facilities provided to tourists. For this parameter only 47 percent of tourists were satisfied. The guide's ability to guide tourists on the trip is also a subject. The guide is considered not to have experience and even good knowledge in providing good services regarding the selection of places or in providing information about a condition that should be accepted by wisatwan well.

The overall perceived service quality by tourists is 52 percent. According to the results of interviews with actors or industry and ASITA (Tourism association) feels that West Sumatra currently feels a lack of Human Resources that can be expected to increase tourism in West Sumatra because indeed education on tourism in West Sumatra is still lacking and even for new universities there are 2 programs study and even then it was only established about 8 years ago with a limited amount of revenue. So that at this time it became a big problem in developing tourism in West Sumatra. Judging from the ability to convey information about culture, the values that exist in West Sumatra are still very limited but the results of the views of respondents are 62 percent. When traveling most of the respondents get information about the culture and values that exist in West Sumatra. Information can be on the way and when doing tourism. But the delivery of information is still constrained by language problems because it is less able to use language that is suitable for tourists and especially if for foreign tourists. Language problems are a big problem at present in the development of tourism in West Sumatra because if you look in the mirror from Bali, they place great emphasis on foreign languages in tourism development while in West Sumatra there has not been a demonstration carried out to date both by the tourism industry and by the government as a regulator.

Tourists if they come to West Sumatra are very difficult to get items that can be used as a characteristic of West Sumatra. Typically West Sumatra goods are in the form of food and there are no other forms of products. The availability of food as souvenirs of West Sumatra is also difficult to find in tourist attractions. The existence of this tourism supporting business such as food where it is not located in one location so that opportunities for entrepreneurial development are also lacking even though the opportunity for it is wide open. The food industry is located in a scattered place, making it difficult for tourists to get it and what happens is that an area is unable to introduce superior products of its region to tourists. As many as 59 percent of respondents stated that they were satisfied with these problems. While the other respondents were not satisfied with this. Besides eating, in fact West Sumatra also has various kinds of regional products such as songket which are woven and also the products of embroidery that are spread over several regions. Tourists find it difficult to get these products slowly. As in Bali there are places that provide almost all of the region's superior products so that the tourists can 
easily get the product. This results in tourism having no impact on the economic activities of local communities. The government's appeal and also the government's planning for this should be done. In order for everything to be implemented, there needs to be a unification of views between the government, society and the tourism industry.

Nature conservation both for the community and for tourists themselves is still very far away. The satisfaction value for respondents is only 39 percent for this. Starting from the cleanliness of tourist attractions that are very lacking, garbage that has not been in place is very detrimental because it can reduce the beauty of the tourist attractions as a whole. The use of nature and preserving nature have not been able to awaken the surrounding community so that maximum conservation has not been seen. The long-term view of the surrounding community is not yet available, in general they only think about giving the impact and benefits at this time. Cleanliness and guarding of the beach and the surrounding environment is very lacking and looks very dirty. There is no public awareness to protect the environment. When viewed from tourism that uses the beach as a tourist place, it has not been able to apply perfection to environmental preservation for the preservation of the future for the environment or nature. This mindset has not been able to enter individuals both from the local community and from tourists who come to visit.

\section{Summary and Implication}

The results show that the parameters of sustainable tourism measured in this study have values that are far from expectations and this is limited by the basic factors that exist in West Sumatra. After calculating all respondents' answers, the value of satisfaction currently felt by tourists has not been seen for sustainable tourism in West Sumatra. Many things are not ready at this time to be able to develop sustainable tourism. Lack of capacity for industry, local communities and government in advancing sustainable tourism into the main hambata. Indeed, it took a long time to be able to synchronize the three elements in order to be able to make West Sumatra develop sustainable tourism. The main research results here are studies on sustainable tourism that have not been done for the context of West Sumatra whereas West Sumatra is one of the world's tourist destinations. Limitations of research in terms of research methods that are only carried out qualitatively and can then be carried out in a qualitative manner to produce key factors in the development of sustainable tourism in West Sumatra.

The results of the research for all parameters are still below average so that the dominant factors as key success factors still need to be considered. Only the availability of food and beverages that get good results while for other parameters still need an in-depth study.Hope the government has made tourism development with a sustainable tourism approach. The occurrence of good cooperation between local communities, government and the tourism industry will be able to create good tourism development so that the government must be able to make this happen in the West Sumatra Provincial Government's Long-Term and Short-Term Development Plan.

\section{Reference}

[1] World Tourism Organization, Study on Chinese Outbound Travel to Africa. Madrid, Spain: UNWTO, 2010

[2] J. Jafari, “On DomesticTourism,” Tour. Recreat. Res., vol. 12, no. 1, pp. 29-31, 1987.

[3] U. N. E. P. and U. N. W. T. Organization, Making Tourism More Sustainable - A Guide for Policy Makers. United Nations, 2005. 
[4] J. Agyeman and B. Evans, "'Just sustainability': The emerging discourse of environmental justice in Britain?," Geogr. J., vol. 170, no. 2, pp. 155-164, 2004.

[5] Chang and Hsiao-Ming, "Study of Tourist Cognized on Costal Sport Tourism Attractions, Travel Experiences, Perceived Values, and Behavioral Intension," J. of Leis. Recreat. Ind. Manag., vol. 2, no. November, pp. 31-51, 2010.

[6] B. Dimitrios, "Marketing the competitive destination of the future," Tour. Manag., vol. 21, no. 1, pp. 97-116, 2000.

[7] L. A. Jackson, "Residents' perceptions of the impacts of special event tourism," J. Place Manag. Dev., vol. 1, no. 3, pp. 240-255, 2008.

[8] D. Gursoy and D. G. Rutherford, "Host attitudes toward tourism: An improved structural model," Ann. Tour. Res., vol. 31, no. 3, pp. 495-516, 2004.

[9] D. W. Ko and W. P. Stewart, "A structural equation model of residents' attitudes for tourism development," Tour. Manag., vol. 23, no. 5, pp. 521-530, 2002.

[10] S. V. Lankford and D. R. Howard, "Developing a tourism impact attitude scale," Ann. Tour. Res., vol. 21, no. 1, pp. 121-139, 1994. 